River, and not far from the Annamite border. The tribes called Phon-tays, live in a sort of semi-independence, like the Laos tribes, in the mountains on the Siamese frontiers. A third tribe inhabiting the region is called by Pére Pinabel the Méos (Mois ?), and are said by him to be in all probability the aborisinal Miao-tsze of South-Western China, although whether he has any ground for this belief beyond the resemblance of the names doe; not appear. At any rate, it is evident from their customs and language that they are Chinese. A fourth tribe is called the Sas, of whom nothing appears to be known except that it fled to the borders of Annam during one of the numerous wars of that region. A long and tolerably detailed account of the manners and customs of the Phon-tays is given, and shorter ones of those of the Mois and Sas. They are all the more interesting that the writer appears to have no idea of ethnology, and therefore is not on the look-out for parallels else, where, but records everything with simplicity and directness. Père Blanck's experiences lay also in the Laos States, on the frontiers of Siam and Tonquin, but to the south of those of his colleague. His paper is simply a record of his journeys among the "savages" in the mountains between the province of Nghe-Ane, the most southern province of Tonquin bordering on Annam, and the Mei Kong River. Both these papers arc taken from the reports of the missions etrangeres. M. du Cailland describes the Quang. si, or Kwang-si, the province of China adjoining Tonquin, and that from which the greater part of the Chinese invading force is drawn. The writer discusses the routes from Langson into China, the river-system of Kwang-si, its administrative divisions, its ethnography, recent history, and the Catholic propaganda there. According to M. du Cailland, the Chinese population there is nothing more than a colony of Cantonese amongst the vast numbers of Miao-tsze and Laos in the western portion. Unfortunately, the writer has omittcd his authorities for this statement, although his references in other portions of the paper are somewhat copious. It would be of great interest to learn on what grounds the wealthiest and most populous province but onc of Southern China is believed to be only a Cantonese colony, while the Miao-tsze, who are generally believed to exist only in small and weak communities scattered over the central part of South-Western China, are masters of this vast district. The geography and ethnography of China must be rewritten, if M. du Cailland is accurate in this portion of his paper.-M. Iluber continues his account of his journey in Central Arabia, which has been already noticed. - Prince Roland Bonaparte describes fourteen voyages to the coasts of New Guinea, made by Dutch Government vessels, between 1876 and 1883 . They went chiefly from Ternate. Each voyage is described in detail, apparently from official sources. The conclusion of the peiper is that it is easy to see from this account that the Dutch have annexed in a definite manner the eastern part of New Guinea to their empire in the Malay Archipelago.--M. Simonin discusses the progress of the Australian colonics commercially and politically.

A t the last meeting of the Gesellschaft fur Erdkunde in Berlin (January 3) Dr. Steinmann read a paper on his journcys in Southern P.tagonia. In $\mathbf{1 8 8 2}$ he went as geo!ogica! assistant to the fourth German expedition to Punta Arenas, mainly with the objec: of studying the Southern Cordilleras. What struck him particularly here was the extraordinary difference in the plant forms to those on the Southern Cordilleras, while on the western slopes vegetation is rich in forms, the climate of the steppes reigns on the castern side. From a geological point of view, the southern point of America is extremely simple in its build, but it is of a different character on the cast and west. On the cast chalk formations occur almost entirely, while on the west, where there are innumerable islands, there is nothing but granite and crystalline rocks. Although the configuration of the coast ha; been studied thoroughly by the English, Dr. Steinmann thinlis that many important questions have still to be settled for instance, whether Laguna Blanca, lying to the north-east of the settlement Kyrsing Water, has an outlet to the west. Ultimately the lecturer reached the Laguna of the third settlement of Santa Cruz, of which it may with certainty be said that was connected until recently with the Pacific Ocean. It may also be concluded that at that time the mainland was much more cut up by channels and waterways than it is now. In May x 883 Tr. Steinmann visited, in the company of Fuegian seal hunters, the islands south of the Straits of Magellan, including Tierra del Fuego. Ulimately, he made his way from the southern point of Amcrica to Bolivia, and here continued his investigations.
THE Society of Naturalists in St. Petersburg has received permission to despatch several of its members to join the Russian representatives on the Afghan Boundary Commission, with the view to the scientific exploration of Central $\Lambda$ sia. The English Commission, which is now on the spot, has, it will be remembered, a geslogist, a naturalist, and topographers amongst its number.

THE Drily Tele $r a p h$ is publishing a series of articles descriptive of the Kilimanjaro expedition, "by it: leader," Mr. H. H. Johnston. They are full of interesting detail.

WiTII the commencement of the new year L'Exploration has taken a new form and a new title. It is now called La Gazet grosraphique et l'Exploration, and is about double its former size, the pages being la:ger and arranged in double columns. We trust that with this improvement there may be a correspond ing advance in its usefulness as a geographical journal.

Petermonn for January contains an article and map on the journey of the pundit $\mathrm{A}-\mathrm{K}-\mathrm{C}$ in Fastern Thibet during the years 1878-82. Dr. Richard Luiddecke writes on the Italian emigration of $\mathrm{r} 883$ from official sources. France takes nearly half of the emigration to European countries, while the State of Ia Plata and North America take the largest share of the extra-European emigration. Dr. Pauli writes on the Cameroons, and Herr Regel describes a journcy from Charjui by Merv to Pandy, and back to Samarkand.

\section{GEOLOGY OF AFGHANISTAN}

THE Times, in the letter from its correspondent with the Afghan Boundary Commission, publishes the following notes supplied by Mr. Griesbach, of the Indian Geological Survey :-

"The hill ranges between Kushkak and Pahri in the Herat valley are all apparently co nposed of rocks bclonging to the Cretaceous and younger periods. So far as I could judge, the ranges are formed by a series of parallel anticlinal folds of the Upper Cretaceous rocks, whic'l in this part of Afghanistan (as in a great part of Persia) are hippuritic beds. They are mostly limestones, dark gray to white, and contain fossils in abundance, among which several spccics of hippurites are the commonest. The igneous rocks which play such an important part within th: hippurite are:a in the Candahar district were also met with here under exactly the same conditions. Basic rocks (trap) are intimately connected with the Cretaceous limestones in this area also, and it would be impossible to distinguish them on anything but a very detailed geological map. Here also the limestone near the contact with the trap (and other igncous rocks) has been converted into a white, fine-grained marble, much used by the natives of Southern Afghanistan for monumental purposes. But by far the most interesting of the igneous rock: is a syenitic granite which appears in several patches. The Karez-i-Dasht is composed entirely of this rock, which is secn to be capped by trap in the surrounding hill ranges. Its age is most probably younger than that of th: trap through which it has burst. This group of rocks, with the exception of patches of younger Tcrtiary rocks, form all the ranges up to and including part of the Chillingak range and pass (near Pahri). The latter range, in which the conspicuous Doshakh peaks are situated, is of great gcological interest. It is an anticlinal fold, the centre and northern axis of which is formed by Palæozoic rocks ; so far, I have only been able to detect Carboniferous fossils in a series of dark blue limestone beds, but it is quite possible that oldel groups are also there. The ravine leading to the high points south of Robat-i-Pai Ziarat has excavaled its course through Carboniferous beds only. The beds dip north and below the younger gravels and fan deposits of the Ileri Rud. But on the right bank of the vallcy, rocks appear again of an entirely different look, and it is quite possible that members of the lower Mesozoic system are represented there. The southern flank of the Chillingak range is formed only by Cretaceous beds-sandstones and shales of the Kojak type, overlaid with hippuritic limestonc near Pahri, The connection of these beds with the Palæozoic strata of the centre is quite hidden. The older river deposits and Dasht beds are clays, sandstonc, and conglomerates much of the same character as already described from the Helmund. They form thick deposits south of P'ahri and in the Heri Rud Vallcy, and I have found remains of mammalian bones in them. 
I believe them to belong to the upper beds of the Siwalik series. In connection with the notes which I was enabled to make during the very hasty examination of the ground travelled over, two facts seem to me to be of considerable importance. The first is the reappearance of older strata than Cretaceous, and strata of distinctly a Himalayan type. One of the great problems of Asiatic stratigraphy is the exact connection of the sedimentary rocks of the North-West Himalayas with the system of the Caucasus, which is again only a continuation of the Alpine system; whether or not the IIIndoo Koosh may be looked upon as a continuation of our North-West Himalayas can only be decided after an examination of its geotectonic features. The connecting link, so to speak, has yet to be found. But the finding of true Carboniferous maine bets containing Protuctus semireticulatus in a range which belongs to the Hindoo Koosh system is a distinct step towards the solving of the great stratigraphical problem of Central Asia. The second fact is of rather an economic than purely scientific interest. I found at more than one place along the route an altered rock near the contact of the hippuritic limestone and the igneous rocks, which in character resembles exactly the gangue in which at Candahar the gold and other minerals occur. So I belicve that a careful search would ccrtainly reveal similar ore-deposits in the Sabzawar and Heral districts. I may bere montion again that the contact rocks in the Candahar district contain cxactly the same minerals as do the altered hippuritic limestone beds of the Banat in Hungary, which also have been disturhed by young granitic rocks."

The same Correspondent, in a previous letter, describes the journey across Seistan from Khwaja Ali to Lash Jowan. The geological features of this part of Seistan arc, according to Mr. Griesbach, extremely simple. Only post-tertiary and recent deposits were met with; the former are fluviatile beds, mostly clays, soft sandstones, and gravels, in character much the same as those forming the tableland of Handesin Tibet, and probably belonging to the same age. The drainage of the area cluring post-tertiary times secms to have been generally identical with the present one, though, perhaps, of a more cxtended nature. 'The recent gravel beds and con glomerates containing worn material from the neighbouring hill ranges arc found in the Farah Rud and the Kash. Rudak in consideratle thicknoss, capping the underlying clays and sandstones of post-tertiary age. Locally, the conglomerate is replaced by a hard limestone breccia, as for instance at Galichah and also the Helmund. But the general character of this cleposit is that of the Indus valley gravels, which are seen to overlie unconformably the younger Siwaliks along the Marri and Bugti hills and the Suliman range. They are found of course within the area of the present drainage. Of useful minerals, only gypsum exists, which is found in the post-tertiary clays, fills fissures and joints, and may perhaps also be found in larger masses. Apparently it is made use of for the manufacture of Gutch or plaster ; traces of diggings for it are found near Lash.

\section{UNIVERSITY AND EDUCATIONAL INTELLTGENCE}

OXFORD. - The following scheme of lectures and classes in Natural Science bas been issued by the Faculty for Lent Term, 1885 :-

In the Physical Department of the Museum Prof. Clifton continues his course on the Galvanometer and Ohm's Law. Iractical instruction in Phy sics is given by the Professor and by Messrs. Walker and Selby. Mr. Walker lectures on the Theory of Errors, and Mr. Selby, on Elementary Mechanics. At Christchurch Mr. Baynes lectures on Electrodynamics, and has a class for practical instruction in Electrical Mcasurements. At Balliol Mr. Dixon lectures on Elementary Magnctisin and Electricity.

In the Chemical Department of the Museum Dr. Odling continues his conrse on the Adipic Compounds. Mr. Fisher lectures on Inorganic, and Dr. Watts on Organic, Chemistry. At Christchurch Mr. Harcourt lectures on the Non-Metallic Elements, and at University $\mathrm{Mr}$. Veley lectures on Physical Chemistry.

In the Morpiological Department of the Museum Frof. Moseley continues his course on the Comparative Anatomy of the Invertebrata. After each lecture special instruction is given in illustration of the lecture. Dr. Hickson lectures on Animal Morphology, Mr. Barclay-Thompson on the Anatomy of Mammalia, Mr. Hatchett Jackson on the Principles of Comparative Embryology and Tevelopment, and Mr. Poulton on the Distribution of Animals.
In the Physiological Department of the Museum Prof. Burdon-Sanderson lectures on the Nervous System, and practical instruction is given by the Professor and Messrs. Dixey and Gotch.

In the Botanic Garden Prof. Bayley Balfour lectures on Elementary Morphology and Physiology, and on the Morphology of the Vascular Cryptogams. Prof. Gilbert lectures on the Result of Field Experiments.

Dr. Tylor lectures on the Early History of Arts and Sciences; Prof. Maskelyne on the Rectangular-axed Crystal Systems; Prof. Prestwich on the Palreozoic and Mesozoic Series.

It is rumoured that the grant to carry on the new physiological laboratory under Prof. Burdon-Sanderson will be opposed in Convocation by the anti-vivisectionists. If this should turn out to he true, it behoves all members of Convocation who side with the advancement of science to come up and record their votes.

Cambringe.-The Board for Physics and Chemistry announces the following lectures for this term :-

Chemistry: Prof. Liveing, General Course; Prof. Dewar, Organic Chenistry; Mr. Main, St. John's, General Course; Mr. Pattison Muir, Caius, General Principles, advanced, especially Physical Chemistry; and Elementary Course for Ist M. B.; Mr. Scott (Prof. Dcwar's assistant) Elementary Organic Chemistry ; Mr. Hoycock, King's, Chemical Philosophy for Tripos, Part I. ; Practical Chemistry, Mr. Sell and Mr. Fenton, three courses of demonstrations, for medical students, Tripos Part I. and Tripos Part II.; Mr. Robinson, Chemistry as applied to Agriculture; Sidney College Laboratory, Demonstrations for Ist M.B., with explanalory lectures.

Physics: Prof. Stokes, Hydrodynamics ; Prof. Thomson, Maguetism; Mr. Atkinson, Trinity Hall, Heat and Hydrostatics; Mr. Glazebrook and Mr. Shaw, Elcmentary and Advanced Physics ; Mr. Hart, St. John's, Light and Elcctricity, elementary and advanced ; Practical Physics, Demonstrations in Cavendish Laboratory, three courses.

Mineralogy : Prof. Lewis, Lectures and Demonstrations.

Mechanism : Prof. Stuart, Mechanism and Applied Mechanics, and Theory of Structures ; Mr. Lyon, Elementary. Mathematics, and Statics and Dynamics.

The Board for Biology and Gcology publish the following list of lectures :-

Geology: Prof. Hughes, Pleistocenc, with special reference to Prebistoric A rchaology; Dr. R. D. Roberts, Physiography, and Class Work; Mr. Marr, Geological Evolution; Mr. T. Roberts, Palæontology; Mr. Teall, Advanced Petrology; Mr. Harker, Elementary.Petrology and Class Work ; Prof. Hughes, Field Lectures.

Botany : Dr. Vines, General Elementary Course, with practical work ; Mr. Gardiner, Anatomy of Plauts, advanced, with practical work; Dr. F. Darwin, General Biology of Plants; Mr. J. W. ITicks Sidney, Elementary Course ; Mr. Potter, Classification of Gymnosperms and Monocotyledons.

Elementary Biology : Dr. Vines and Mr. Sedgwick.

Zoology: Prof. Newton, Geographical Distribution of Vertebrata; Mr, Wcldon, Practical Morphology, Invertebrata; Mr. Sedgwick, Anatomy and Embryology of Vertebrata, elementary; Mr. Harmer, Osteology of Vertebrata, and advanced course on Arthropoda; Mr. Gadon, Palæontology and Affinities of Groups of Mammalia,

Physiology: Prof. Foster, Elementary Course; Mr. Lea, Chemical Physiology; Mr. Langley, Adranced Course; Dr. Gaskell, Circulation and Respiration, advanced; Mr. Hill, Class for and M.B.

FIuman Anatomy: I'rof. Macalister, Organs of Circulation and Respiration; Demonstrations in Osteology.

The Board for Mathematics announces the following lecture on higher mathematics this term :--Prof. Stokes, Hydrodynamics; Prof. Adams, Lunar Theory; Prof. Thomson, Trinity College, Electromagnetism ; Mr. Hobson, Christ's, Planetary Theory ; Mr. Glazebrook, Theory of Light; Mr. Forsyth, Functions of Complex Variables ; Dr. Resant, Analysis, Definite Integrals, Calculus of Variations and Differential Equations; Mr. Mollison, Fourier's Series and Conduction of Heat; Mr. Pendlebury, Analytical Optics; Dr. Routh, Attractions and the Figure of the Earth ; Mr. Stearn, Electrostatics.

Mr. G. J. Romanes, LL.D., F.R.S., has been appointed to deliver the Rede Lecture this year.

R. E. Fry, Clifton College, has been elected to a Natural Science Open Exhibition at King's; W. J. Elliott, Newcastle 